\title{
Tutoring fundamental tool for university students
}

\section{La tutoría herramienta fundamental para el discente universitario}

\author{
PONCE-CONTRERAS, María Guadalupe†*, GONZÁLEZ-ÁLVAREZ, Mireya del Carmen, PÉREZ- \\ BRIONES, Nancy Griselda and TELLO-GARCÍA, María Ascención
}

Universidad Autónoma de Coahuila. Faculty of Nursing “Dr. Santiago Valdés Galindo”, Mexico.

ID $1^{\text {st }}$ Author: María Guadalupe, Ponce-Contreras / ORC ID: 0000-0003-3174-9682, CVU CONACYT ID: 947777

ID $1^{\text {st }}$ Co-author: Mireya del Carmen, González-Álvarez / ORC ID: 0000-0002-3061-4439, CVU CONACYT ID: 958313

ID $2^{\text {nd }}$ Co-author: Nancy Griselda, Pérez-Briones / ORC ID: 0000-0001-6903-4039, CVU CONACYT ID: 370311

ID $3^{\text {rd }}$ Co-author: María Ascención, Tello-García / ORC ID: 0000-0002-9057-6497, CVU CONACYT ID: 68385

DOI: $10.35429 /$ JTER.2020.18.6.29.40

Received July 25, 2020; Accepted December 30, 2020

\begin{abstract}
The objective is to analyze whether or not there is a relationship between learning, tutorials, and the values presented by the students of the Faculty of Nursing. Population: made up of 480 students. The sample was 178 students and it is non-probabilistic. Instrument, consists of 66 reagents and is divided into 4 sections, a centesimal scale is used. Cronbach's Alpha Reliability of .87. Results, are analyzed: frequencies and percentages, integrational level and all possible regressions. The ages range from 18 to 26 years, the majority are women. The learning that occurs in this is closely related to the reflection that takes place, strengthening in the subject values such as friendship, happiness and trust, improving in the same way personal growth and the development of skills, intelligence is another of the learning values that are improved in the subject when we link it with the tutorials and their tutors. What is intended with the results is to bring together managers and teaching staff and show the results so that relevant decisions are made, especially that it is given the relevance that this program has and the benefit that students obtain by providing them.
\end{abstract}

\section{Resumen}

El objetivo es analizar si existe o no relación entre los aprendizajes, las tutorías y los valores presentados por los estudiantes de la Facultad de Enfermería. Población: compuesta por 480 estudiantes. La muestra fue de 178 estudiantes y no es probabilística. Instrumento, consta de 66 reactivos y se divide en 4 secciones, se utiliza una escala centesimal. Fiabilidad alfa de Cronbach de .87. Se analizan los resultados: frecuencias y porcentajes, nivel integracional y todas las regresiones posibles. Las edades oscilan entre los 18 y los 26 años, la mayoría son mujeres. El aprendizaje que se da en esta está íntimamente relacionado con la reflexión que se produce, fortaleciendo en la asignatura valores como la amistad, la felicidad y la confianza, mejorando de igual manera el crecimiento personal y el desarrollo de habilidades, la inteligencia es otro de los valores de aprendizaje que se mejoran en la asignatura cuando la vinculamos con los tutoriales y sus tutores. Lo que se pretende con los resultados es acercar a directivos y profesorado y mostrar los resultados para que se tomen decisiones relevantes, especialmente que se le dé la relevancia que tiene este programa y el beneficio que obtienen los estudiantes al brindarlos.

Estudiantes, Tutoría, Aprendizaje Teaching and Educational Research. 2020. 6-18:29-40.

\footnotetext{
* Correspondence to the Author (Email: mariaponce@uadec.edu.mx)

$\uparrow$ Researcher contributing as first author.
} 


\section{Introduction}

Tutoring arises as a companion to formal and informal education. Etymologically, tutela (from the Greek tutelae) means protection. However, the meaning of tutor has had variations throughout history, from the ancient Greeks, who used it to define the responsibility acquired by a "respectable" person, until it constituted the materialization of an effort to reduce failure rates, academic backwardness and desertion, as well as promoting the comprehensive education of students in Higher Education institutions Soto (2020).

The central element of tutoring is the elucidation, from the communicative interaction, of the student's resources to face different situations, assuming an active position in front of the world. Thus, the tutor-tutored communication assumes the form of change and assumes prior knowledge of both parties, where the tutor will be the one who promotes, through reflection, clarification in the teaching-learning process. Orientation at the university, in general, and university tutoring, in particular, is and should be considered as an essential factor for improving the quality of teaching. Abad (2020) states that college tutoring is related significantly with study habits, which leads us to recommend, the tutoring program covers specific topics of study habits and study planning strategies

Rodríguez, (2019), raised the need for a different tutor according to the level of what has to be learned and the characteristics of the ward; establishing a connection between the purposes of the university (teaching, research and extension) and the type of teacher it needs.

The National Association of Universities and Institutions of Higher Education (ANUIES) proposed in 2000, as a viable and strategic resource to improve the quality of student performance, a methodology to establish tutoring programs in its affiliated institutions, based on the recognition that their situation was far from what was stated in the objectives of a higher education system of the magnitude and importance of ours.
Thus, the institutions undertook arduous work to incorporate the proposal, supported by a training process that has evolved, not only in function of their particular needs, but also in recognition of the new perspectives for training professionals and the current concept about a fundamental actor in this process: the teacher.

At the university as at any academic level, tutoring, through various modalities and applications, has been settling in the world of education at any of its levels and stages, both the student and the teacher must acquire a commitment so that the objective After the tutoring is fulfilled, the tutor must create a climate of trust to favor the teaching-learning process, must motivate the student so that their academic training improves and becomes active and constructivist, must support the student in the development of the use of strategies for their studies and to stimulate the student to develop competencies that help them integrate into a society. In an investigation carried out in 2017 , it is mentioned that accompanying a student during the course of his university life leaves the great experience of being friends in a situation of support and guidance, and at the same time the satisfaction of being academic when we show ourselves as the guide of knowledge that dispels the concerns of our youth.

The following research is carried out with the aim of analyzing the relationship that exists between tutorials, values and learning presented by students of the Faculty of Nursing, this arises from observing that students and tutors do not take responsibility for carrying out the accompaniment process. Some factors that were taken into account to determine how the tutoring program is carried out are: how often are the sessions and duration. The methodology that was used started from the design of an instrument, in which the participants, according to their experience, gave their point of view about the tutoring program carried out in the Faculty, then the database was created in order to perform the statistical processing of each level. The benefit that will be given to the institution will be to let the staff in charge of the tutorials know, if both tutors and students take responsibility for the process that must be carried out in the program. 
To finalize an important point that will be developed within the research project, it will be the intervention proposal that will be proposed as possible solutions to the problems that are detected in the research development. Overall objective. Analyze the relationship between tutorials, values and learning presented by students of the Faculty of Nursing.

\section{Theoretical Framework}

Tutorials: The need to implement alternatives to improve school quality and efficiency is a concern in all societies. Thus, arises a proposal to generate new changes; The Institutional Tutoring Program is oriented in two aspects: qualitative and quantitative. From a quantitative level, it seeks to reduce school failure or dropout, reviewing and analyzing the factors, influences and statistics of school failure, dropout, low productivity and, on a qualitative level, it is proposed to respond by attending to the socioaffective needs of the students. students who favor or not academic achievement. Instead, for Abad, K. (2019). He affirms that university tutoring is significantly related to study habits, which leads us to recommend that the tutoring program covers specific topics of study habits and study planning strategies.

In this sense, the priority orientation towards self-directed learning (learning to learn, learning to undertake and learning to be) and comprehensive training with a humanistic vision, constitute a great value to achieve the objectives, with which the adaptation of the student the school environment and the strengthening of the work study, are specific elements to which importance is given. One of the most important quality indicators in education is to have efficient and timely individual and group care services for students through tutorials (Villanueva 2015).

According to ANUIES (2019), tutoring consists of a process of accompaniment during the training of students, which is specified through personalized attention to a student or a group of students, by academics who have been trained for this function, conceptually based on learning theories.
The author Sánchez (2013) explains that: A tutorial is an aid or guidance to the student or a group that the teacher and / or tutor can carry out with a systematized set of educational actions focused on the student and that is complementary to teaching compared to group (pp. 30).

The Technological University of Nezahualcóyotl, cited by Villanueva (2015) reveals the characteristics that a tutoring should have:

1. It is considered a substantive task that includes a set of educational activities to promote the integral development of the student.

2. Guides and accompanies the student during his teaching-learning process.

3. Supports in situations related to the psychoemotional development of the student.

4. Guides and channels the student to address psycho-pedagogical, socio-cultural, socioeconomic and academic factors.

5. Implements structured activities based on the development of a Tutorial Intervention Plan, based on the Tutoring Program as appropriate.

6. Carries out organized and systematic work, supported by instruments for diagnosis, monitoring and evaluation, which allow for qualitative and quantitative measurement of the impact of the tutorial actions on student performance.

7. It involves various levels and models of intervention within the teaching activity.

8. Plans educational actions centered on the student.

9. Tutoring can be individual or group.

10. It is done in moments.

It is important to highlight the difference between a tutoring and academic advising. The latter is an activity assumed by teachers for very precise objectives, such as thesis directions, project directions, coordination of professional practices and resolution of doubts by the student. 
On the other hand, the tutoring aims to guide and monitor the integral development of students in the cognitive, affective and social aspects of learning, it is for this reason that the tutor must always be attentive to the development of student learning and channel the student in case You have trouble getting your child specialized care. Tutoring is a guiding process in which teachers participate to help students in their learning process, which has become a possibility to improve school achievement. In the tutorials, the teachers are directly in charge of attending to the students about the process they follow to learn, and they can design methodological strategies that allow them to attend to the learning style of each student. (Nando, 2010).

For Sánchez (2013) mentions that tutoring in an academic accompaniment process during the training of students, tending to improve their academic performance, achieve graduation profiles, develop study and work habits, whose basic tool is found in the tutorial orientation processes and channeling to other support entities. This accompaniment is specified through personalized attention to a student or a group of students by teachers, who for this purpose have been trained and appointed as tutors. It offers students:

1. Reinforce the teaching-learning process and study habits.

2. Channel counseling for subjects that the institution provides, and offer reinforcement options that are organized to support the leveling of basic knowledge in subjects with a high failure rate.

3. Channel the psychological support that the institution provides, or where appropriate to external institutions.

4. Guide and advise on the definition of their study plan, that is, on the planned choice of their reticular sequence throughout their career.

5. Guide and inform about its organization and institutional procedures, such as scholarships, school insurance and other benefits that the institution offers its students.
Nezahualcóyotl

Technological University (Op.Cit) and mentions that there are two classifications of tutoring which are: Individual Tutoring. Activity that facilitates the identification of the particular needs of the student to evaluate, guide, channel and follow up on their academic trajectory that allows them to take advantage of their individual strengths.

Group Tutoring. Activity through which group needs are identified to evaluate, guide, channel, monitor and propose alternative solutions to the problems detected, in order to promote an integration that positively affects academic achievement, in addition to favoring interpersonal relationships (2015, pp. 8)

Based on the foregoing below, an analysis of the tutoring process carried out in different universities and technological ones is shown. Citing the example of the UAdeC, it can be seen that the approach goes beyond establishing a link between the student and the teacher as their program is conceived in the CEA program, we can see how they seek to reduce dropout rates and their failure rates within your students through personalized monitoring of your students. The Monterrey Technological Institute seeks to strengthen its students by having the participation of parents within the teaching-learning process, providing them with information, academic support, means and stimuli necessary for their comprehensive training and that they can have all the necessary tools for their performance in the labor field. As can be seen, each campus presents variables in its tutoring programs, however all seek the integral development of it by educating through the support of the teaching staff to reduce the dropout rates from schools and the failure rates. Instead, for the authors. Ceniz Soto, L., Colunga Santos, S., \& Ortiz Pérez, R. (2020). In his research "Professionalization of the guiding function of the tutor in Higher Education" he states that in the primary results of the study they showed that the need for training for the guiding function in tutors of Higher Education is fundamental. For this reason, it is considered extremely important to prepare teachers to play this fundamental role in supporting their students. 
Regarding the concept of Learning: When we hear the word learning, study and school come to mind for most of us. We think of subjects or skills that we are trying to master, such as algebra, Spanish, chemistry. However, learning is not limited to academics. We learn every day of our lives. Babies learn to move their limbs; teens learn the lyrics to all their favorite songs; Middle-aged people learn to change their diet and exercise habits, and every few years we learn to find a new attractive dress style. Likewise, it continues to be mentioned that learning occurs when the experience generates a relatively permanent change in the knowledge or behaviors of the individual. The change can be deliberate or unintentional, for the better or for the worse. To be considered learning, this change should occur through experience: through the interaction of a person with their environment. Changes caused only by maturation Woolfolk (2014).

According to Ardila (2015), he says that learning is a process that is manifested by adaptive changes in individual behavior as a result of experience. It is a relatively permanent change in behavior that occurs as a result of practice (pp. 17-18). The author Ruiz (2012), refers that learning can also be a stable change that exists as a result of experiences in people, this cannot be explained by a transitory state of the organism, which is maturation, through which new ones are assimilated information be it facts, concepts, procedures, values etc. We think that we can all build new meaningful and functional mental representations that are called knowledge, which over time can be applied in different contexts where we learn. In addition, it says that all new learning is by definition dynamic, which is why it is susceptible to being revised and readjusted from new cycles. That is why it is said that learning is an unfinished and spiraling process. It can be said that learning is the progressive qualification of the structures with which a human being understands his reality and acts in front of it (starts from reality and returns to it). (pp. 30)

However, Warren (2016) mentions that: Learning can be an individual activity that takes place in a social and cultural context.
This is the result of individual cognitive processes through which new information (facts, concepts, procedures, values) are assimilated and internalized, new meaningful and functional mental representations (knowledge) are also built, which can then be applied in situations other than those contexts where they were learned. Learning not only consists of memorizing information, it is also necessary other cognitive operations that involve: knowing, understanding, applying, analyzing, synthesizing, and evaluating. In any case, learning always involves a change in the physical structure of the brain and with it its functional organization (2016, pp. 19-20).

For Bowel (2017), the definition of learning ensures that there are certain processes that take place when a person is about to learn; For example, students, in their activities, perform multiple cognitive operations that make their minds develop easily. These operations are when the person perceives, observes, reads and identifies, once this is done a retention process is carried out where it is memorized or remembered and finally, it is reflected, that is, it is analyzed, compared, ordered, interpreted and criticize what he has perceived. One can also speak of creative, expressive, symbolic and expressive operations of the kind of practices; in the former, it is explored, transferred and predicted as it is created or imagined; in the latter it is represented or communicated through the use of languages. And in the last one, what has been learned is applied using the necessary tools (pp. 12-14).

Learning also tells us about learning theories, which helps us understand, predict and control human behavior, in turn developing learning strategies and trying to explain how subjects access knowledge. Its object of study focuses on the acquisition of skills and abilities in reasoning and in the acquisition of concepts (Conceptions About Learning, 2017).

On the other hand, from the perspective of these authors Pozo-Sánchez, Santiago; López-Belmonte, Jesús; Fuentes-Cabrera, Arturo and Moreno-Guerrero, Antonio-José. (2020). In their research called "Incidence of retro-innovation in higher education. Radio and television as complementary tools in the use of the teaching model known as flipped learning". 
The study focuses on analyzing the scope of two methodological approaches to verify their impact on various academic indicators. The experimental design is quantitative, descriptive and correlational. The study includes a control group and an experimental group in a sample of 60 Spanish university students. The control group has followed a traditional training methodology, without using technological resources. The experimental group has developed a pedagogical action through flipped learning supported by classic resources such as radio and television. For data collection, a questionnaire has been used that has been designed and validated for this research. The results reflect that the experimental group has obtained better evaluations in collaboration, motivation, active role, interaction, digital competence and learning achievements, over the control group. It is concluded that the combination of flipped learning together with innovative retro media is effective in improving academic indicators in higher education. What makes us reflect on what we are doing with our university students.

Instead, from the perspective of the author Valencia Morocho, C. A. (2020). In his research called "Virtual education in critical thinking in students of a private university in Lima" he refers to the fact that the application of virtual education today significantly influences the critical thinking of students.

Currently in the academic-educational process due to the COVID-19 pandemic, he has conceived a pedagogical turn in his traditional conception of learning; As it has been necessary, to avoid massive contagions in schools and educational institutions, to adopt the virtual modality as a development point of the current academic period initially scheduled, planned, designed, to be carried out in person, which forces to re-plan based on the use of the various resources in relation to communication and information technologies (ICT) available in various social contexts (Londoño, 2020).

In this period of confinement due to COVID-19, part of psychopedagogy should not only be limited to managing processes in accordance with the generation of learning in the virtual modality, assumed as an emergency approach substitute for face-to-faceity.
Also, it must consider the situation of students who do not have sociological conditions such as internet connectivity, technological equipment, together with those who have some type of disability that minimizes or prevents their participation in an active way. In this sense, Vohlonen (2020), states:

In Ecuador, only 37 percent of households have internet access, which means that 6 out of 10 children cannot continue their studies through digital platforms. The situation is more serious for children in rural areas, only 16 percent of households have this service. However, in the country 9 out of 10 households do have a television or cell phone, which is an alternative to reach children through these means (p. 1).

A situation that deserves due attention because it breaks with the idealism of achieving a uniform education and under equal conditions, when it comes to addressing the educational emergency caused by COVID-19, through the virtual modality. A similar cause is raised by (Fernández-Enguita, 2020), when indicating that there are gaps that cause distancing between Spanish students, among which are:

1. Access gap (having or not having access to connection and technological devices). The distribution is very unequal according to the socioeconomic level of the students: at the low level, $14 \%$ of the students do not have a computer at home, while $44 \%$ only have one. These figures contrast with those of the high socioeconomic group, where $61 \%$ have three or more computers at home, $31 \%$ have two, and only $8 \%$ have only one. Access gap (having or not having access to connection and technological devices). The distribution is very unequal according to the socioeconomic level of the students: at the low level, $14 \%$ of the students do not have a computer at home, while $44 \%$ only have one. These figures contrast with those of the high socioeconomic group, where $61 \%$ have three or more computers at home, $31 \%$ have two, and only $8 \%$ have only one.

2. Use gap (time of use and quality of this). Spanish students are at similar levels of use compared to other countries. And although differences are barely shown by autonomous communities, they are found by socioeconomic level with respect to the use of ICT devices at home 
3. School gap (teacher skills, availability of resources and adaptation of online teaching support platforms). According to the management teams, approximately $50 \%$ of them affirm that their teachers have the professional capacities and resources to learn to integrate digital devices in teaching; The same percentage as that of students who are in centers that have an effective online platform.

This scenario, coupled with the fact that the World Bank of Education (2020) indicates that education was already in crisis before the pandemic, makes the situation more challenging for those who are in charge of the responsibility of training future students. generations, more in a context of uncertainty because there is no certainty as to how long the educational isolation due to COVID-19 will last. Therefore, teachers must resort to educational innovation as an ally to promote adequate tools to promote learning (Jiménez-Galán, 2017). Which also implies researching the course of events to learn by doing in a global and dynamic society.

As for Values, which is another axis of the research: We value and are valued. We value the actions of others, we value the people around us and we value the objects that surround us; simultaneously, others value our actions and value our person. Humans do not know how to live without valuing; We do not have an indifferent and passive attitude towards reality, but we feel it beautiful or ugly, good or bad, pleasant or painful (Larroyo, 2015, pp. 187). Talking about values, ethics, training, value or moral seems easy. However, throughout history we see that there have been and are many schools, and their positions in this regard. For the purpose of this contribution, we include in general terms a definition of value, as well as some of the theories that have contributed to studying the moral development of the individual and that in some way could be used as support or guide when implementing some didactic or methodological strategies (Secretary of Public Education of Coahuila, 2019).
On the other hand, the Secretary of Public Education (2019) defines values as: VALUE: it is the character, quality or characteristic for which a being, fact or thing awakens appreciation, esteem or admiration. Based on the above, we can affirm that in our daily life there are different types of values: economic, nutritional, artistic, ethical, and so on.

Fundación Televisa (2013) mentions that, if education wishes to form upright human beings, its task is to strengthen the individual and socio-cultural values indicated in article 3 of our constitution. We attribute a value to an action when we affirm that it is good, we attribute a value to a person when we say that it is beautiful, we attribute a value to an object when we affirm that it is useful.

Values can vary greatly across cultures, families, or individuals. There are different types of values:

Family values: They refer to what the family considers to be good and what is bad. They have to do with the personal values of parents, those with which they educate their children, and those that children, as they grow, can contribute to their family. Family values are the first that our will learn.

Sociocultural values: These are the values found in society at the time we live. These values have been changing throughout history and may or may not coincide with family values.

Personal values: Are those that the individual considers essential and on which they build their life and their relationships with others. They tend to be a combination of family values and sociocultural values, in addition to those that the individual himself contributes to himself according to his personal experiences.

Material values: Material values are those that allow us to survive and are important insofar as they are necessary. At present, we are experiencing a rise at a social level, in material values: money, cars, houses and what is associated with all this, such as prestige, good economic position, etc. 
Ethical and moral values: They are those that are considered essential for the proper coexistence of individuals in society. Education in these values depends, to a large extent, on their being contemplated in those values that the family considers essential, that is, that among the family values transmitted to the children are these essential ethical-moral values such as those shown then:

Respect: It has to do with accepting others as they are, with their virtues and defects, recognizing their rights and needs. Saying things politely, without hurting, violent or insulting anyone, are signs of respect.

Sincerity: Sincerity is the pillar on which trust is based. So that our children do not lie, we must not abuse punishment: children lie out of fear of punishment.

Courtesy: It has to do with respect, consideration and manners. It does not have to do with not being able to do some things because it is not polite, but in doing them saying "please", "thank you" and "can I?"

Tolerance: It has to do with acceptance and respect for people who are different, what is strange, unknown or unusual.

Responsibility: It has to do with the confidence we have that our children will know how to take on some tasks and will fulfill them. It has to do with the awareness that actions or non-compliance with them have consequences for other people or for our own child.

Equality: Right of all human beings to be treated equally before the law.

Self-esteem: Valuing attitude towards oneself. The responsibility that parents have in transmitting these values to our children is crucial. Values are not transmitted through genetics, which is why it is so important to take them into account in education. But we must know that values are not taught independently of the rest of things, neither through great explanations or by giving a list of what we consider correct and what not, hoping that our children will memorize it (Vázquez, 2017, pp. 19- twenty)
Values are transmitted through practical example, through everyday life, our behavior on a daily basis, in what children observe their parents doing. Today, we try to educate our children in respect, tolerance, renouncing violence, consideration and courtesy, but we live in a society in which our children soon discover that other very different values also prevail, such as leadership., selfishness, the accumulation of money, the lust for power, and even racism and violence. Family values will determine, to a large extent, the good judgment our son has to consider these other values as acceptable or despicable, or to know how to adapt them to his good opinion in the best possible way.

\section{Methodology}

Population: The population is made up of 480 students from the Faculty of Nursing, which are divided into a degree in nursing, a leveling course and a master's degree in older adults.

Sample: In this research, the sample that will be used is the non-probabilistic one since the choice of elements does not depend on probability, but on causes related to the characteristics of the researcher. The sample consists of 178 students from the 4th, 6th and 8th semesters, these students were chosen since the entrance of the generations the tutoring program was in force.

Instrument: The instrument of this research was designed to analyze the impact of tutorials, values in the learning of students in the Bachelor of Nursing Unit Saltillo, this instrument was applied to 178 students of the Bachelor level of the aforementioned school, it was It consists of 66 reagents which are divided into 4 sections. In the first section, in the upper part of said instrument the shields of the 2 institutions that endorse this research are located and the name of each institution, later the instruction is located to answer the part of general data in which variables such as sex, age, if carried tutorials or not among others. These variables will be answered according to the experience of each participant. In the second section you will find the instructions on how that part will be answered where it is indicated that to answer the questions a centesimal scale $(0-$ 100) will be used, this section is intended to know to what extent the tutorials that are carried out in the faculty comply with aspects such as: help, guidance, monitoring, among others. 
In the third part it is questioned whether the values by the students and teachers are related to the tutoring program, in this section there is a table with the values of the students and another with the teachers in which the answer will be a scale from 0 to 100 . In the fourth part it is asked whether carrying out the tutorials benefits the students' learning with elements such as experience, skills, memorizing information, among others. Finally, thanks are shown for having collaborated in answering the survey.

\section{Statistical Analysis Plan: Before carrying out the readings of the present investigation, the statistical processing of the descriptive level (Frequencies and percentage) was carried out, here the general data of the people surveyed is analyzed, then the integrational level (Factor analysis) was carried out, this level is used to the study and interpretation of the correlations between a group of variables and finally the integrational level (regression analysis) this level is used for the study and interpretation of the correlations between a group of variables.}

\section{Results and Discussion}

Summary of results: This chapter shows the results extracted from the statistical processes. Crombach's Alpha reliability analysis was .87 . To objectify the elements of statistical processing, in which the levels of statistics, frequencies and percentages, integration level and regression were analyzed.

Frequencies and percentage: Regarding the level of frequencies and percentage, it can be observed that the participants who answered the survey, their ages ranged from 18 to 26 years, the majority were women (82\%), the rest were men. The Faculty of Nursing has the tutoring program, however, there are people who do not know this information. There is an irresponsibility on the part of the tutors since the sessions that the students must attend have never attended and the tutors have never assigned a date for the activities, a minority mention that each month they attend the sessions for the duration of each session lasts from one hour to two hours, the way the tutorials are carried out is face-to-face.
Likewise, it is highlighted that tutoring is considered an educational strategy for the attention of students, in which the student helps the student in the academic activities they carry out in their institution such as: development, personal growth, among others, understanding of information between others. The tutorials deal with problems related to study, reading and comprehension skills, learning difficulties, test anxiety, emotional stability, attitudes towards the profession, career options, among others. When students perceive that they have the learning skills and strategies to be successful, they are more likely to want to continue and finish their studies, in addition to the impact that tutorials have on learning, the student takes values as a main role when they are present In tutoring the values that stood out the most in this process are those of respect, responsibility, tolerance, and patience.

The tutor must promote the learning of the students, be a guide, guide and provide the necessary tools for them to generate their own knowledge. The priority activities of the tutorial action is the development of strategies, such as the organization of the text, programming of study activities, application of techniques that strengthen cognitive skills, among others, that contribute to facilitate the adaptation of the student to the school environment to improve their study skills and increase their school performance.

Integrational level: Factor analysis. Problem solving despite being steps below orientation shows the great inference that it has when interacting with the learning processes, teaching, academic activities and help showed high values showing the great interaction they have with intelligence in the subjects. Therefore, we can see how the tutoring program, together with the variables that characterize it, strengthen the links with learning at all times.

Relational level: Regression analysis. Multiple regression: This statistical analysis begins with the multiple selection of variables, considering intelligence as the dependent variable, which in this case was chosen based on factor analysis with the intention of looking for possible proposals for the sustaining approach. 
The tutor must create a climate of trust to favor the teaching-learning process, must motivate the student so that his academic development improves and becomes active and constructivist, must support the student in the development of the use of strategies for their studies and stimulate the student. student to develop competencies that help them integrate into a society.

Multivariate selection of variables: This statistical analysis begins with the multivariate selection of variables, considering as dependent variables, study, academic interest, teachinglearning process, teamwork, which in this case were chosen based on factor analysis with the intention of look for possible proposals to the sustaining approach. According to what is observed in the tutoring program, the tutors carry out the function of accompaniment, help, guidance, training and in the event of needing help for some kind of problem, the tutor channels the student to a specialist, the attention that the tutors They give is personalized and during the tutorials they develop personal growth and study habits.

\section{Conclusions}

Regarding the general objective of this research (to analyze the relationship between tutorials, values and learning presented by students of the Nursing Degree, it can be mentioned that it was verified by factor 3 within the factorial analysis since it mentions that within the framework of the tutoring program, the learning that takes place in it is closely related to the reflection that takes place strengthening in the subject values such as friendship, happiness and trust, improving personal growth and development in the same way of skills, intelligence is another of the learning values that is improved in the subject when we link it with tutorials. On the other hand, with respect to the basic questions, it can be highlighted that the values of honesty, respect, responsibility, and patience are the values that the students take into account at the time of being in the tutorials, this could be known through the Factor analysis in factor 1. In the Nursing Degree tutoring program, the academic support given by the tutors benefits the student to develop study habits using didactic resources to understand the information that is given, this gives an answer to the benefit that tutorials have on student learning.
Among the findings that were found in this research are that it was thought that the tutoring process was not carried out, but at the time of making the results everything came out the opposite of the tutoring process being carried out properly.

\section{Recommendations}

That the tutoring process be monitored so that all students attend their sessions. That the tutorials are managed as professional practices so that the student and the tutor take their role and carry them out. Carry out more research on the subject of tutoring so that the educational institution knows how effective this program is. That the parents sometimes be part of the tutoring sessions, this to support the students and that they feel motivated to continue with their studies and help them in their personal development. According to the results of this research, it is intended a posteriori to carry out a comparative study with another educational institution at the Bachelor's level of the same Autonomous University of Coahuila.

\section{References}

Abad Escalante, K. M. (2020). Tutoría universitaria y hábitos de estudio en estudiantes universitarios de la Facultad de Ingeniería de una universidad de Los Olivos.

ANUIES Estatuto de la Asociación Nacional de Universidades e Instituciones de Educación Superior. (En línea). México, ANUIES. http:// tutoria.indd 115 29/3/11 15:49:17 116 . La tutoría. Una estrategia innovadora www.anuies.mx/la_anuies/normatividad/estatut o2016/estatuto_2016.pdf [Consultado: 03 de noviembre de 2019]

Ardila, R. (2015). Psicologia del Aprendizaje. Mexico: Siglo Veintiuno.

Banco Mundial de la Educación (2020). Banco Mundial de Educación y COVID-19. [World Bank for Education and COVID-19]. Recuperado de https://url2.cl/BsqVi

Bowel, E. (2017). Teorias del Prendizaje. Mexico: Trillas. 
Ceniz Soto, L., Colunga Santos, S., \& Ortiz Pérez, R. (2020). Profesionalización de la función orientadora del tutor en la Educación Superior. (Original). Roca. Revista Científico Educacional De La Provincia Granma, 16, 897908. Recuperado a partir de https://revistas.udg.co.cu/index.php/roca/article/ view/1807

Concepciones Acerca del Aprendizaje. (2017). Revista Electronica Psicologia Cientifica.

Fernández-Enguita, M. (2020). Una pandemia imprevisible ha traído la brecha previsible. [An unpredictable pandemic has brought the predictable gap]. Cuaderno de Campo (31 marzo). Recuperado de https://url2.cl/msU2j

Hernándes, R., Fernández, C., \& Baptista, P. (2006). Metodología de la investigación. México: McGrawHill.

Jiménez-Galán, Y. (2017). Innovación educativa y docencia ¿falla el protagonista?: el caso ESCOM. [Educational innovation and teaching: does the protagonist fail ?: the ESCOM case]. RIDE. Revista Iberoamericana para la Investigación y el Desarrollo Educativo, 8(15), $710-$

734. https://dx.doi.org/10.23913/ride.v8i15.317

Larroyo, F. (2015). Ciencia de la Educación. Argentina: Porrua.

Londoño, O. D. R., \& Mora, J. L. D. (2020). COVID-19 La transformación de la educación en el Ecuador mediante la inclusión de herramientas tecnológicas para un aprendizaje significativo. HAMUT'AY, 7(2), 64-74

Monterrey, T. d. (14 de Mayo de 2017). Programa de Tutoría. Obtenido de http://www.itesm.mx/wps/portal?WCM_GLOB AL_CONTEXT=/migration/SIN2/Sinaloa/Prog ramas+educativos/Prepa+Tec/Preparatoria+Bili ng_e/Programa+de+tutor_a

Nando, U. A. (15 de Enero de 2014). Tutorías UAN. Obtenido de www.tutoria.uan.mx

Nezahualcóyotl, U. T. (2015). Programa Institucional de Tutorias. 61.
Pozo-Sánchez, S., López-Belmonte, J., FuentesCabrera, A., \& Moreno-Guerrero, A. J. (2020). Incidencia de la retro-innovación en educación superior. Radio y televisión como herramientas complementarias en el uso del modelo de enseñanza conocido como aprendizaje invertido. Formación universitaria, 13(3), 139-146.

Ruiz G., García, T Y., \& Abreu, L.F (2012). Modelo Integrador de la Tutoría. De la dirección de tesis a la sociedad del conocimiento. Revista Mexicana de Investigación Educativa, 11(31), 1363-1388. Recuperado de:http://www.comie.org.mx/revista/v2018/rmi e/index.php/nrmie/ article/view/738

Sánchez, L. (2013). tutorías: Orientación; realidad académica para el aprendizaje. Revista Iberoamericana para la Investigación y el Desarrollo Educativo, 14.

Sánchez, S. (2014). Diccionario de las Ciencias de la Educación. México: Aula Santillana.

Soto, L. C., Santos, S. C., \& Pérez, R. O. (2020). Profesionalización de la función orientadora del tutor en la Educación Superior. (Original). Roca. Revista científico-educacional de la provincia Granma, 16, 897-908

Tamaulipas, U. A. (Septiembre de 2011). Tutoría académica y tutoría de tesis.

Televisa, F. (20 de mayo de 2013). Tipos de Valores. Obtenido de http://www.fundaciontelevisa.org/mejorenfamil ia/formacion/tipos-de-valores

Valencia Morocho, C. A. (2020). Educación virtual en el pensamiento crítico en los estudiantes de una universidad privada de Lima, 2020 .

Vázquez E. (2017). El Profesor Tutor en el proceso de Universalización de la Educación Superior. Evento Internacional de Pedagogía. La Habana, Cuba.

Villanueva, R. L. (2015). El Aprendizaje Cooperativo: Un modelo de intervención para los programas de tutorías escolar a nivel superior. Revista de la Educación Superior. 
Vohlonen, A. (2020). COVID-19: Cómo asegurar el aprendizaje de los niños sin acceso a Internet. [COVID-19: How to ensure children's learning without Internet access]. Recuperado de https://url2.cl/RyPdp

Warren c., H. (2016). Diccionario de psicología. México: Santillana.

Woolfolk, A. (2014). Psicología Educativa. México: Pearson Addrson Wesley 